\title{
Conversion as a mechanism of hybridization: the institutional transfer of industrial relations and vocational training from western to eastern Germany
}

\section{Geny Piotti}

Department of Social Sciences,University of Osnabrück, Seminarstraße 33, 49074 Osnabrück, Germany; e-mail: geny.piotti@uni-osnabrueck.de

Received 22 December 2009; in revised form 8 December 2010

\begin{abstract}
Looking back over the two decades since German unification, the main questions I want to answer are to what extent and through what mechanisms the transfer of the system of industrial relations and vocational training-two cornerstones of the West German model-has occurred in eastern Germany. The literature argues that institutional transfer very often leads to a process of hybridization in institutions. However, the concept of hybridization has also been criticized as being mainly descriptive and vague about the actual mechanisms of hybridization. In this paper I argue that these mechanisms should be specified further and suggest that the hybridization approach can be fruitfully linked to recent theories of institutional change. As far as the transfer of industrial relations and vocational training from western to eastern Germany is concerned, I argue in particular that hybridization has mainly occurred through what institutional literature has recently defined as the mechanism of conversion.
\end{abstract}

\section{Introduction}

The problems of institutional change and the role of external institutional transfer experienced a revival with the fall of the Berlin Wall and the transition of the former socialist countries from planned economies to market economies. Eastern Germany is an important exceptional case in many ways. Unlike those that took place in other countries, East Germany's transition has had a clear model to follow: the West German one. In fact, the process of German reunification was characterized by an extension of the West German constitution and institutions of the social market economy to the East. So, in contrast to other countries of the Eastern Bloc, less space has been left for previously existing institutions to play a role (Streeck, 1997; Wiesenthal, 2004).

Looking back over the two decades since German unification, the main questions I wish to answer are to what extent and through what mechanisms ${ }^{(1)}$ the transfer of the system of industrial relations and vocational training has occurred. The West German system of industrial relations, founded on sector-based collective agreements and codetermination at the company level, and the system of vocational training, built on learning at school and apprenticeship in companies, are considered to be two cornerstones of the West German model and are indicated in the literature as important sources of West Germany's success as a production system in the 1980s (Streeck, 1997). ${ }^{(2)}$

(1) According to Mayntz (2004), "the term 'mechanism' refers to recurrent processes linking specified initial conditions and a specific outcome" (page 241, my emphasis).

(2) Despite the fact that collective agreements and vocational training are national institutions, they are implemented at different levels. Collective agreements are defined mainly at the level of the Land (federal state) and the sector, but local unions and employers' associations as well as works councils are involved in ensuring the actual signing and implementation of collective agreements at the firm level. 
Literature has argued that transfer has often led to processes of hybridization (Bluhm, 2001; Dörrenbacher, 2004; Dörrenbächer et al, 2000; Schmierl, 2003). The hybridization approach points to the fact that one-to-one transfers of institutions do not take place very frequently. On the contrary, it is more often the case that institutions, organization forms, and best practices need to be adjusted according to the characteristics of the new context (Boyer, 1998; Tolliday et al, 1998). However, the concept of hybridization has also been criticized as being mainly descriptive or vague about how the mechanisms intended as processes of hybridization should occur (Rehder, 2003).

In this paper I will argue first that hybridization processes have taken place despite the formal transfer of the whole set of institutions which should have made eastern Germany as a whole more similar to the West and despite already existing similarities between institutions in the West and those in the former German Democratic Republic (GDR). Second, mainly because of the similarities generated by eastern Germany's inheritance of the same institutional setting as that in western Germany, hybridization has mainly occurred by what Thelen (2004) and Streeck and Thelen (2005) define as a mechanism of conversion. This means that hybridization can take place through actors who, in addressing different (mainly challenging) situations, try to provide answers by first looking into existing rules - that is, appealing to special cases and extending already existing but marginal norms so that both the aims and the targets of those rules change-and with them the institution as a whole.

In the following chapter I will focus on the concepts of hybridization and conversion in institutional transfer. In chapters 3 and 4 I will illustrate how the respective systems of industrial relations and vocational training have been transferred and implemented in eastern Germany.

\section{Institutional transfer and hybridization through conversion}

Recent literature from the tradition of political economy, historical institutionalism, and regulation theory has focused on the problem of institutional change and on the mechanisms that can explain evolutionary and revolutionary change (Boyer, 1998; Campbell, 2004; Pierson, 2000; Streeck and Thelen, 2005). Although these studies are, surprisingly, not connected with each other, an attempt to correlate them can give a better account of change in general and of institutional change through transfer - the topic which I am dealing with in this section-in particular. A comparison of these studies can help us to focus on the actors and the mechanisms behind hybridization.

By focusing on the consequences of the foreign context for transplants, organization studies in the tradition of regulation theory identify hybridization and revolutionary change through innovation as possible forms of change in transnational organizations. Although the concept of hybridization was originally used for the study of organizations, it has increasingly been applied to the interpretation of institutional change, in general (Boyer, 2005), and institutional change as a consequence of the exposure of national systems to international pressure, in particular (Deeg, 2001; Höpner, 2005; Schmierl, 2003).

Starting from the idea that "a system that functions in one space will not necessarily function in another [hybridization] involves the insertion of a business system into a new society or context, and the processes of adaptation and learning involved" (Tolliday et al, 1998, page 4; Boyer, 1998). The results of transfer in terms of hybridization, revolutionary change through innovation, or failure depend upon the level of definition of the external firm's model of production and on the permissive or fitting character of the context (Berger, 1996; Tolliday et al, 1998). As Boyer (1998) indicates, 
the more structured the model of origin and the more rigidly it is applied in a less permissive context, the greater the probability that major changes or even failure will occur. While transfer is regarded as an important source of innovation and revolutionary change, processes of hybridization in the new context are considered to be the norm. ${ }^{(3)}$

However, whether change is evolutionary or revolutionary, or adaptive or innovating, should not be seen as the result of a deterministic process. It is important to underline the role of actors: "Open as it is to the strategies of actors, this process is historically contingent" (Boyer, 1998, page 38).

In order to avoid determinism as well as statements that reduce change to a matter of historical contingency, it is necessary to look at regularities in actors' strategies and mechanisms that lead to hybridization in different contexts. In the case of the transfer between West and East, I deal with the transfer and implementation of a relatively rigid type of model into a context characterized by stronger economic uncertainty.

Critics of this approach assess that hybridization does not provide a conceptual solution to the dilemma of institutional change, but only "a catchy description of the problem" (Rehder, 2003, page 63). Rehder, for instance, criticizes some interpretations of the concept that equate hybridization with the simultaneous presence of both continuity and discontinuity and advocates for further attention to the mechanisms of change.

I argue that the hybridization approach mentions at least one mechanism through which hybridization occurs - namely, through the search for functional equivalents (Tolliday et al, 1998). However, the way in which such functional equivalents are produced is still an open question within the theoretical framework of the hybridization approach. In particular, the process of searching for functional equivalents should be specified further. A dialog with recent research on institutional change and its mechanisms is required.

Recent institutional analysis has suggested conversion as an important mechanism of institutional change. When actors address uncertain situations - that is, because of environmental challenges or when new power relationships emerge-existing institutions are likely to be adapted to serve new goals or fit the interests of new actors (Streeck and Thelen, 2005; Thelen, 2004).

Because the whole set of institutions was transferred, western companies that decided to produce in the East did not necessarily have to-and to a certain extent they could not-reinvent the wheel. Rather than bearing the costs of trial and error, looking at ways to adapt to the already existing rules is likely to become a more feasible strategy, at least to the extent to which existing rules provide windows of opportunity for companies to adapt to different economic conditions and to follow their own interests redefined in the light of the new production context.

Since transferred institutions are always incoherent to a certain extent, actors who operate in the new context can draw on these incoherencies in such a way that, say, exceptional rules can become the norm and the goals and targets of the transferred institutions change. In the next sections I will show that institutional transfer in eastern Germany in the fields of industrial relations and vocational training has led to processes of hybridization through conversion.

(3) Regulationists explicitly distance themselves from the determinisms of the country-of-origin effect (Harzing and Sorge, 2003; Whitley, 1994) and any automatic efficiency based on "one best practice" (Womack et al, 1990). 


\section{The transfer of the dual system of industrial relations}

The institutions of collective bargaining (Tarifverträge), codetermination (Mitbestimmung), and the union and employer organizations governing them were all transferred to the eastern context upon reunification. Developments in the early years have allowed some researchers to speculate on the success of the transfer of social partnership-not merely in the form of substantial union membership and affiliation to employers' associations (at least, in the case of major western firms), but also by dint of the unions' capacity to mobilize workers and possibly establish a basis for the development of a collective identity that could even reinvigorate social partnership in the West. The union's victory in the strike in Saxony in 1993 against the unilateral attempt by the entrepreneurs' associations to refuse a $26 \%$ wage increase established by collective agreements could be interpreted in this light. The lack of associational commitments on the part of small local companies in the East was interpreted as a temporary strategy for overcoming uncertainty that would not exclude the signing of collective agreements once firms gained some stability (Turner, 1997; 1998). As far as codetermination is concerned, Turner (1998) argues that previous practices of cooperation among the workforce in facing the deficiencies of planned production were an important precondition for support of the works councils. The theoretical consequences of this view are the assessment of the primacy of institutions in shaping behavior compared, for example, with interest and culture. However, against the background of a successful formal transfer of institutions and organizations, institutional legitimation and implementation have turned out to be more problematic over time.

The transfer has occurred, in fact, with strong organizational pressure to preserve Tarifautonomie (bargaining autonomy) ${ }^{(4)}$ and to pursue a strategy of high wages in eastern Germany. On the one hand, this strategy supported the interests of western entrepreneurs who feared price competition from the East; on the other hand, it reinforced the organizations by enlarging their membership base (Lembruch, 1994).

The fact that in the first years of reunification union membership was very high was largely the result of the almost automatic transfer of members from the East German unions to the West German ones. Rising unemployment and decreasing company size then led to a loss of potential members for the unions as well (Artus, 2001; Schroeder, 2000). Not only did membership soon start to decline, but also the identification of the workforce with the unions proved to be lower than their commitment during the strike of 1993 had been (Fichter, 1997). Problems with representing eastern workers arose because the difficult job situation discouraged taking on voluntary functions within unions; this combined with a lack of adaptation of union policies to eastern German needs. Industrial relations were rapidly considered very much a West German institution.

On the side of the employers' associations, the processes of privatization of the former Kombinate led to increasing heterogeneity among eastern German firms [between those already privatized, those still under the Treuhand, small and mediumsized enterprises (SMEs) and large corporations, and between the different sectors] and to difficulties in terms of representation (Artus, 2001; Czada and Lembruch, 1998). The membership base of the employers' associations, by contrast, had never been very broad because of the low industrial density in the new Länder. The West-inspired policies of high wages, pursued by the bargaining partners (Tarifpartner) while there was a substantial lack of representation and uncertainty about the economic situation in eastern Germany, proved to be inadequate.

(4) Tarifautonomie means that collective bargaining between unions and employers' associations is constitutionally protected and autonomous from the influence of the state (Badura, 1974). 


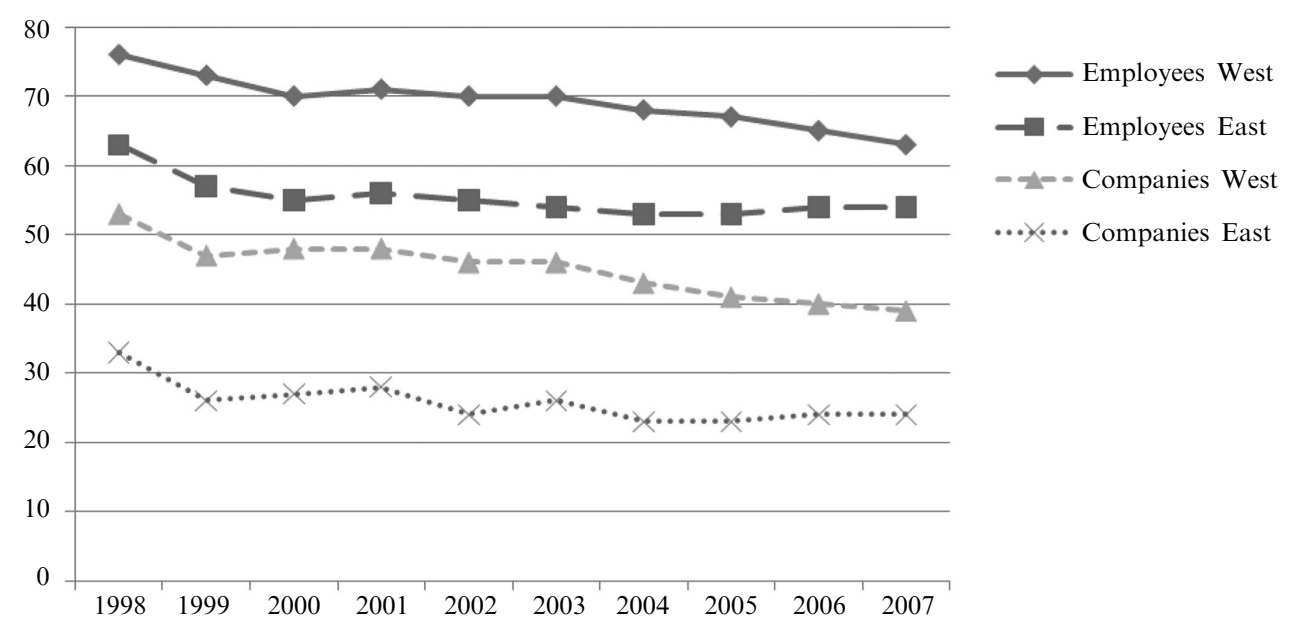

Figure 1. Coverage of collective agreements in Germany: percentage of employees and companies, $1998-2007$ (source: author's calculation based on data of the WSI-Tarifsarchiv, 2008, http://www.boeckler.de/549_19392.html).

These factors soon led to a crisis of wage definition through collective agreements which caused the coverage of collective agreements to be systematically lower than in western Germany (figure 1). ${ }^{(5)}$ Only $20 \%$ of companies in eastern Germany were adhering to a collective agreement in 2007 (in West Germany, adherence was 36\% (table 1).

Table 1. Bargaining coverage in West and East Germany: 2000 and 2007 (percentage share of companies) (source: IAB, 2008).

\begin{tabular}{lcccccc}
\hline & 2000 & & & 2007 & \\
\cline { 2 - 3 } & West & East & & West & East \\
\hline No collective agreement & 32 & 42 & & 38 & 45 \\
Orientation to collective agreements & 20 & 31 & & 26 & 31 \\
$\quad$ without subscription & 3 & 4 & & 3 & 4 \\
Company agreements & 45 & 23 & & 36 & 20
\end{tabular}

Note: Companies include private business, without agriculture and nonprofit organizations.

Moreover, collective agreements increasingly presented 'hardship clauses' (Härtefallklauseln) and 'opening clauses' (Öffnungsklauseln), and agreements at the firm level (Hausverträge) have expanded and changed their usual function. Hardship clauses enable companies set wages below the level defined by collective agreements in the event of a company crisis. As in the case of the hardship clauses, opening clauses were originally conceived of in West Germany as 'codetermined' deviations from collective agreements to guarantee a degree of flexibilization of working time. As such, the two exceptions are not regarded as formally violating the collective agreement itself but are potentially sources of institutional change if, instead of being implemented only in exceptional cases, they become increasingly adopted. Some $13 \%$ of companies covered by collective agreements have opening clauses. Although flexibilization of working time remains the main reason for the introduction of opening

(5) Western Germany, however, is experiencing similar trends to those in eastern Germany. The legitimation for collective agreements is declining there as well. 
clauses, $23 \%$ of them are also used for flexibilizing wages (IAB, 2008). In eastern Germany, wage levels defined by collective agreements can be reduced by up to $10 \%$.

Since only works councils, unions, and management are involved in the company agreements, while employers' associations are left out of the negotiation processes, agreements at firm level represent important institutional deviations in industrial relations. Originally, company agreements - the most famous example is that of Volkswagen (VW) - were used to define labor conditions that exceeded those outlined by sector collective agreements. Works councils enjoyed a strong position in companies, and unions had still a great deal of influence due to their presence on the board of directors. By contrast, the trend with regard to establishing company agreements in eastern Germany was to bond eastern German companies to some form of union-coordinated wage definition in the very initial phase, before the transfer of the Tarifpartner's organizational setting had occurred. Later on, it was increasingly motivated by the goal of gaining greater independence from the institutional constraints posed by the system of industrial relations and therefore reducing costs. ${ }^{(6)}$ In $2007,4 \%$ of eastern German companies had adopted a company agreement. In western Germany, this number was only $2 \%$.

Finally, the bargaining coverage of collective agreements and company agreements differs according to company size. Despite the differences between East and West, collective agreements and company agreements seem to increase with increasing company size, while smaller companies often decide not to sign any agreement at all (table 2). For small and medium-sized eastern German enterprises, in particular, high wages independent of productivity increases could mean an exit from the market. Since workers were prepared to accept lower wages in exchange for job security, entrepreneurs increasingly refused to abide by collective agreements or often avoided any form of associational commitment.

Table 2. Bargaining coverage according to company size: percentage share of companies, 2004 (source: IAB-Betriebspanel 2004, in Ellguth and Kohaut, 2005).

\begin{tabular}{|c|c|c|c|c|c|c|}
\hline \multirow[t]{2}{*}{$\begin{array}{l}\text { Number of } \\
\text { employees } \\
\text { (30 June 2004) }\end{array}$} & \multicolumn{2}{|c|}{$\begin{array}{l}\text { Sector collective } \\
\text { agreements }\end{array}$} & \multicolumn{2}{|c|}{$\begin{array}{l}\text { Company } \\
\text { agreements }\end{array}$} & \multicolumn{2}{|c|}{$\begin{array}{l}\text { No agreement (thereof } \\
\text { orientation to collective } \\
\text { agreements) }\end{array}$} \\
\hline & West & East & West & East & West & East \\
\hline $1-9$ & 36 & 15 & 2 & 3 & $63(36)$ & $82(39)$ \\
\hline $10-49$ & 53 & 31 & 3 & 7 & $44(53)$ & $62(48)$ \\
\hline $50-199$ & 59 & 45 & 8 & 16 & $33(53)$ & $39(49)$ \\
\hline $200-499$ & 70 & 57 & 11 & 19 & $20(59)$ & $25(57)$ \\
\hline$\geqslant 500$ & 81 & 65 & 12 & 20 & $8(52)$ & 15 (47) \\
\hline Total & 41 & 19 & 2 & 4 & $57(40)$ & 77 (40) \\
\hline
\end{tabular}

Note: Companies include private business, without agriculture and nonprofit organizations.

(6) Cost reduction has been the leitmotif of VW's institutional strategies in recent years, which has also led to changes within the corporation in the field of industrial relations, even at the headquarters. While in eastern Germany, VW refused to transfer the costly company agreement one to one and opted instead for the clearly cheaper Saxony IG-Metall collective agreement; in Wolfsburg the deviating potentials of the Hausvertrag have been used in order to experiment with new ways of organizing production and achieving cost reduction. The so-called $5000 \times 5000$ agreement instituted in 1999, in fact, established a clear cleavage in work regulation between conventional VW workers and formerly unemployed workers in the special program. 
However, recent studies on eastern Germany show that collective agreements still represent a point of reference for the definition of wages. In order to limit interregional free-riding caused by the migration of young skilled workers to the West, where wages for the same qualifications are still higher, wages in eastern Germany have to be kept relatively high. As a consequence, even unilateral setting of wages cannot ignore collective agreements completely (table 2).

The apparent contradiction inherent in companies' orienting themselves toward collective agreements without actually signing them can also be explained by the strategies of employers' associations and the growing mistrust towards union politics in the East (Silvia, 1997). In Saxony, for instance, employment associations have been openly encouraging companies to join their associations without signing collective agreements. In open disagreement with this kind of politics, VW-which, in contrast to its branches in the West, adheres to the local collective agreements in Saxony-has opted out of the Saxony collective agreement and joined the Brandenburg collective agreement (Keune et al, 2009). If the strike that took place in eastern Germany in 1993 could be interpreted as a success, there is little doubt that the strike called for exactly ten years later in order to achieve the 35-hour work week was a failure which has contributed to further undermining the trust in unions and hence also to favoring more decentralized forms of negotiations.

Today, the second pillar of the German system of industrial relations-codetermination at the company level-is also becoming less institutionalized and much more voluntary, and is changing its nature at the same time. In particular, important differences exist between smaller local companies and larger western ones.

The solidarity and flexibility required at the workplace to face production shortfalls in GDR firms, as well as the critical phase of privatization of the large Kombinate, in which management strongly cooperated with the works councils to ensure the survival of the firm, had supported the idea that the transfer of codetermination could count on previous cooperation practices and solidarity. However, enthusiasm for works councils soon declined. Some studies on codetermination still show differences between East and West (Bosch et al, 1999) - in particular, a lower share of works councils in companies throughout eastern Germany compared with the West. In 2007, 39\% of the employees in eastern Germany were in companies with works councils (in western Germany, 46\%). Only $7 \%$ of the employees could count in eastern Germany on other informal types of workers' representation (for instance, through spokesmen) compared with $11 \%$ in western Germany (Ellguth and Kohaut, 2008).

The cooperation between management and labor in the former state enterprises during the economic transition from a planned to a market economy was driven more by critical circumstances than by processes of institutionalizing codetermination inherited from the West (Schmidt, 1998). By contrast, in smaller local companies the presence of works councils is very low. Here, their coverage does not differ substantially from that in western Germany. However, the lack of employee representation at the firm level not only depends on the companies' structural characteristics, such as their size or leadership (for instance, family-owned companies). In the East, works councils are further hindered by the lack of tradition in industrial relations and a lack of support from the workforce (Schmidt, 1998).

In companies without collective agreements, ${ }^{(7)}$ works councils have to fulfill increasingly wider functions, such as that of wage definition. At the same time, their legitimation by the management goes as far as the interests of the works councils 
coincide with those of the companies. Increasingly, works councils are considered not so much as actors of codetermination, but rather as intermediaries between management and employees which can potentially improve communication between them (Keune et al, 2009).

\section{The transfer of the dual system of vocational training}

The second milestone of the West German model-the dual system of vocational training - was transferred to the East like other institutions as well. In contrast to the system of industrial relations, however, the former GDR enjoyed a strong tradition of apprenticeship at both the school and company levels, albeit not in a market context. This is not only because the genesis of vocational training dates back to the Wilhelminian era ${ }^{(8)}$ - long before the separation of the two Germanies-but also because after the Second World War, the GDR exceptionally did not break with the past in the field of vocational training. In fact, vocational training took place in the large public corporations - the Kombinate - and at school, whereas professional schools were mainly internal to and under the jurisdiction of the companies as well. In a socialist system of production subordinated to state plans, vocational trainingand education in general-was conceived of as a contribution to the development of both the national economy and of a socialist personality. However, even in this nonmarket context, state-owned firms had to accept the responsibility for education and guarantee the transfer of theoretical knowledge and practical know-how by integrating trainees into the production process. ${ }^{(9)}$ It was not uncommon for larger companies to train young people formally assigned to other firms (Busemeyer, 2009). Because of the similarities between the two systems, the transfer from the West to the East took a relatively short time and was characterized, at least initially, by cooperation between eastern and western institutional actors.

However, despite the parallels between the transferred West German system and that in the GDR, the literature generally points to significant difficulties in implementation in eastern Germany. The problems encountered are essentially due to economic uncertainty and a substantial lack of firms in eastern Germany, which causes a mismatch between the demand of young people for apprenticeships and the actual supply that the companies can provide (Brussig, 2003; Busemeyer, 2009; Thelen, 2007; Ulrich and Eberhard, 2008). While in 2007, 95\% of trainees were trained within the regular dual system of vocational training, only $71.6 \%$ were covered by the dual system in the East (table 3). ${ }^{(10)}$ Currently, even those young people who have the possibility of being trained within the framework of the traditional dual system have no guarantee that they will be offered a job at the end of their training. Moreover, training is costly for the firm involved, and it is even more costly if there is no prospect of integrating the apprentices afterwards, or if interregional free-riding phenomena occur as a consequence of wage differentials between East and West (Keune et al, 2009).

${ }^{(8)}$ For a recent overview of the history of vocational training, see Thelen (2004) and Greinert (2008).

${ }^{(9)}$ For an overview of vocational training in the former GDR, see Busemeyer (2009) and Locke and Jacoby (1997).

(10) The literature also points to regional disparities in the implementation of vocational training within eastern Germany. This is not only because of the regional economic disparities and firm concentration that characterize the former GDR, but also because of the role played by politicians. In areas where they were able to involve civil society, regions were better able to promote vocational training as well (Culpepper, 2003). 
Table 3. Financing vocational training in East and West: public and dual vocational training: percentage of trainees (31 December 2006) (source: Bundesministerium für Bildung und Forschung, 2008).

\begin{tabular}{|c|c|c|c|}
\hline Financing schemes & West & East & Germany \\
\hline Federal-Länder Program East ${ }^{\mathrm{a}}$ & 0.0 & 9.5 & 2.0 \\
\hline (Additional) Länder schemes ${ }^{a}$ & 0.5 & 2.8 & 1.0 \\
\hline $\begin{array}{l}\text { Vocational training for disadvantaged } \\
\text { young people (school-based training) }\end{array}$ & 2.2 & 12.8 & 4.5 \\
\hline Vocational training for disabled ${ }^{b}$ & 2.3 & 3.3 & 2.6 \\
\hline Total vocational training in public schemes & 5.0 & 28.4 & 10.1 \\
\hline Total traditional dual vocational training & 95.0 & 71.6 & 89.9 \\
\hline
\end{tabular}

The low density of firms and the difficult economic conditions in eastern Germany have therefore often led to regional education policies based on a stronger role for schools and training centers as compared with firms.

Vocational training becomes part of the more general development policies supported by the federal state and the Länder, the latter having authority over the form and the recipients of support. At the end of 2006, 12.3\% of vocational training was financed by the federal state and the Länder (table 3). According to the agreement between the Federal Ministry of Education and Research and the eastern Länder in 2007, about $€ 68$ million should be invested in supporting training and professional education in the East between 2007 and 2010. The state, in particular, can finance part of the vocational training in single firms as well as within workplace learning partnerships carried out by networks of firms (Verbundausbildung). Finally, it can finance the entire cost of company external training such as that provided by professional schools and training centers. The Länder decided to devote about three quarters of the general sum to finance training in workplace-learning partnerships and one quarter to full-time professional education at school and in training centers (Bundesministerium für Bildung und Forschung, 2008).

In addition, compared with the West, eastern regions finance six times more vocational training jobs using funds from the Federal Employment Office devoted to the integration of disadvantaged young people into training programs (table 3 ). However, this surprising difference should not lead to the erroneous conclusion that the share of young people who need special sociopedagogical support is also six times higher in the East than in the West. The differences in the use of this form of public support are rather the result of a different interpretation of the term 'disadvantaged' in the East. In fact, in the implementation of the public support scheme, the concept has been stretched in such a way that the borders between economically and socially disadvantaged young people have become quite blurred (Bundesministerium für Bildung und Forschung, 2008).

If we take a closer look at the two alternative solutions to the regular vocational training supported by the Länder, they are not completely new and do not emerge as ad hoc answers to the problem of the lack of opportunities for vocational training for young people in eastern Germany. In fact, professional schools were already present in the West but were used marginally or were confined to particular professions - mainly 'women's professions', such as those in the fields of social and health care-or to some creative professions not regulated by the Handicrafts Regulation Act: jewelry making, 
carving, violin making, ceramics and glass, as well as design. The incapacity of the dual system to provide training opportunities and hence to fulfill its public educational function in contexts of structural crisis, such as that which took place in eastern Germany after unification, led to an extension of the principle and the organizational forms of full-time professional schools to further types of professions that had traditionally been a prerogative of the Vocational Training and Handicrafts Regulation Acts. It is only since unification that professional schools have been called upon to fulfill a different function - namely, balancing out the weaknesses of vocational training (Greinert, 2008). These developments have also affected formal regulation. The German Vocational Training Act was, in fact, reformed in 2005 (Federal Ministry of Education and Research, 2005). Among other things, the new text makes access to examinations by the Chamber of Industry and Commerce easier for young people who have received qualifications in full-time professional schools (Thelen, 2007), which can be considered as a step towards establishing equivalency between the two forms of training.

Although part of the literature considers workplace-learning partnerships to be a real eastern German innovation (Buss and Wittke, 2006), the partnerships in the East were certainly inspired by principles and practices that were already present in vocational training in the West and, as mentioned before, even in the former GDR. In fact, the origins of workplace-learning partnerships can be traced back to the medieval tradition of 'journeyman's travels' (Wanderschaft) in which craftsmen moved from one firm to another in order to enhance their own expertise before becoming masters (Rauner, 2003). Later on, cooperation in training activities among companies was relatively widespread and found its raison d'être in chapter $23, \S 2$ of the Vocational Training Act - that is, as a way of addressing the incapacity of companies to fulfill their training functions (Federal Ministry of Education and Research, 2005). Indeed, workplace learning was initially conceived of as a form of mutual help when, because of the limits imposed by their specialization, small companies in particular could not cover all the contents formally required by the Vocational Training Act (Rauner, 2003). Taking part in a training consortium had the function of closing the gap in fragmented knowledge and providing trainees with mostly non-firm-specific but general knowledge regarding their professions. As mentioned before, even during the GDR, journeyman apprenticeships through different firms were not an unfamiliar option. However, the present revival of workplace-learning partnerships in eastern Germany and their financial support by the state serves a different de facto goal: the reduction of the mismatch between demand and supply in vocational training. Publicly financed workplace-learning partnerships have become incentives for companies aimed at reducing their costs and organizational efforts.

\section{Concluding remarks}

I had two major goals with this paper: assessing the extent to which institutional transfer from western to eastern Germany has occurred and detecting the mechanisms behind possible processes of hybridization associated with the transfer. I explicitly used the framework of the hybridization approach and intended to define it further. The concept of hybridization is a useful tool for three reasons: first, it explicitly considers institutional transfer as a source of institutional change. In particular, such change can lead to further diversification and fragmentation in the same institutional field when different solutions are adopted by different types of actors. This could be demonstrated even in the case of eastern Germany, where companies from the West had the opportunity to continue following previously existing rules. 
Second, the degree of change depends on how the institutions to be transferred and the contexts in which they are transferred fit together, considering that different kinds of companies - small eastern companies compared with large western ones-which have also different degrees of experience and tradition in the transferred institutions, represent potentially different kinds of environments in which the rules are being implemented.

In fact, in the field of industrial relations, major deviations took place especially in local SMEs, for which the uncertainty of the market conditions in the East is higher and in which entrepreneurs had not experienced industrial relations in the form applied in the West before. Even in this case, however, collective agreements did not cease to be a reference point for companies as well. In the field of vocational training, the general principles of which had also been applied during the GDR, and through which not only the future of companies but also that of young people is at stake, the role of schools has become important, but solutions that maintain the option of training in companies associated with fewer costs for them is (at least politically) clearly preferred.

Third, hybridization implies that actors are trying to find functionally equivalent solutions to institutional devices that do not work in the new context and/or with which actors' interests are at odds. However, the hybridization approach does not specify how they do this, what they are searching for, and how: basically, what mechanisms lead to hybridization.

The case of the transfer from the West to the East has shown that, if the institutions transferred are rigid and the uncertain economic situation makes adhering to norms too costly, the main actors - in this case usually companies and employers' associations - might decide to deviate from the norms at least to the extent to which these deviations fit their interests and do not affect their reputation too much. The analysis of two central aspects of the German model-namely, the dual system of industrial relations and vocational training - in eastern Germany suggests conversion to be an important mechanism through which functional equivalents, and hence hybridization, are generated after the transfer from the West to the East. Conversion could be observed in the extension and modification of goals that has followed the strategic use of exceptional rules like opening clauses and hardship clauses, along with the diffusion of company agreements in eastern Germany.

In the case of apprenticeships, we have observed a rebalancing of the in-plant and school-based components of training (Thelen, 2007), the diffusion of practices of workplace-learning partnerships, as well as a shift in the governance principle of vocational training. While this was once a public good carried out by private organizations, the state now becomes crucial when private firms are no longer able to fulfill the function. This has happened not least through the stretching of exceptional norms on public support of vocational training.

In the fields I examined, the functional equivalents identified were not completely new options: either they were present in the legislation already or constituted existing legitimated practices. In any case they were conceived for other actors and goals and had previously played a more marginal role. This paper suggests that institutional functional equivalents can first be found in the incoherences of rules - that is, in the open spaces left by legislation - and that the exceptions to the rules might be an important place for actors to look if they want or need to deviate from the roles but still maintain a link to the rules themselves. 


\section{References}

Artus I, 2001 Krise des deutschen Tarifsystems: Die Erosion des Flächentarifvertrags in Ost und West (Westdeutscher Verlag, Wiesbaden)

Badura P, 1974,"Arbeitsgesetzbuch, Koalitionsfreiheit und Tarifautonomie" Recht der Arbeit. Zeitschrift für die Wissenschaft und Praxis des gesamten Arbeitsrechts 27 129-138

Berger S, 1996, "Introduction", in National Diversity and Global Capitalism Eds S Berger, R Dore (Cornell University Press, Ithaca, NY), pp 1-25

Bluhm K, 2001, "Exporting or abandoning the 'German model'?: Labour policies of German manufacturing firms in Central Europe" European Journal of Industrial Relations 7153 - 173

Bosch A, Ellguth P, Schmidt R, Trinczek R, 1999 Betriebliches Interessenhandeln. Zur politischen Kultur der Austauschbeziehungen zwischen Management und Betriebsrat in der Westdeutschen Industrie volume 1 (Leske and Budrich, Opladen)

Boyer R, 1998, "Hybridization and models of production: geography, history and theory", in Between Imitation and Innovation: The Transfer and Hybridization of Productive Models in the International Automobile Industry Eds R Boyer, E Charron, J Ulrich, S Tolliday (Oxford University Press, Oxford) pp $23-56$

Boyer R, 2005, "Coherence, diversity and the evolution of capitalism: the institutional complementarity hypothesis" Evolutionary and Institutional Economics Review 2 43-80

Brussig M, 2003, "Institutionen und Organisationen: Bedingungen und Blockaden ihrer Kopplung. Beispiele aus der ostdeutschen Industrie" Berliner Debatte Initial: Zeitschrift für sozialwissenschaftlichen Diskurs 56118 - 143

Bundesministerium für Bildung und Forschung, 2008, "Berufsbildungsbericht 2008",

Bundesministerium für Bildung und Forschung, Berlin, Bonn, http://www.bmbf.de/pub/bbb.08.pdf

Busemeyer M, 2009 Wandel trotz Reformstau: Die Politik der beruflichen Ausbildung seit 1970 (Campus, Frankfurt am Main)

Buss K-P, Wittke V, 2006, "Die andere Seite industrieller Entwicklung in Ostdeutschland: Erfolgreiche Unternehmensstrategien und ihre soziale Einbettung" SOFI-Mitteilungen 34 $91-109$

Campbell J L, 2004 Institutional Change and Globalization (Princeton University Press, Princeton, NJ)

Culpepper P D, 2003 Creating Cooperation: How States Develop Human Capital in Europe (Cornell University Press, Ithaca, NY)

Czada R, Lembruch G, 1998 Transformationspfade in Ostdeutschland (Campus, Frankfurt am Main)

Deeg R, 2001, "Institutional change and the limits of path dependency: the case of German finance", DP 06, Max-Planck Institute for the Study of Societies, Cologne, http://www.mpifg.de/pu/mpifg_dp/dp01-6.pdf

Dörrenbacher C, 2004, "Fleeing or exporting the German model? The internationalization of German multinationals in the 1990s" Competition and Change $8443-456$

Dörrenbächer C, Fichter M, Neumann L, Tóth A, Wortmann M, 2000, "Transformation and foreign direct investment: observations on path dependency, hybridisation and model transfer at the enterprise level" Transfer $6434-449$

Ellguth P, Kohaut S, 2005, "Tarifbindung und betriebliche Interessenvertretung: aktuelle Ergebnisse aus dem IAB-Betriebspanel” WSI-Mitteilungen $7398-403$

Ellguth P, Kohaut S, 2008, "Tarifbindung und betriebliche Interessenvertretung: aktuelle Ergebnisse aus dem IAB-Betriebspanel" WSI Mitteilungen $9515-519$

Federal Ministry of Education and Research, 2005, "Reform of vocational education and training in Germany: the 2005 Vocational Training Act", http://www.bmbf.de/pub/ reform_vocational_education.pdf

Fichter M, 1997, "Unions in the new Länder: evidence for the urgency of reform”, in Negotiating the New Germany Ed. L Turner (ILR Press, Ithaca, NY) 87-112

Greinert W-D, 2008 Geschichte und Reform des deutschen Systems der Berufsausbildung (GAFB, Frankfurt am Main)

Harzing A-W, Sorge A, 2003, "The relative impact of country of origin and universal contingencies on internationalization strategies and corporate control in multinational enterprises" Organization Studies 24187 -214

Höpner M, 2005, "What connects industrial relations and corporate governance? Explaining institutional complementarity" Socio-Economic Review 3331 - 358 
IAB, 2008, “IAB Betriebspanel 2007”, Bundesministerium für Verkehr, Bau und Stadtentwicklung, Bericht Ostdeutschland, Berlin, http://www.bmi.bund.de/SharedDocs/Downloads/BODL/IAB/ panel2008_ergebnisse.pdf?_blob=publicationFile

Keune M, Piotti G, Tóth A, Crouch C, 2009, "Testing the West German model in East Germany and Hungary: the motor industry in Zwickau and Györ", in Innovation in Local Economies: Germany in Comparative Context Eds C Crouch, H Voelzkow (Oxford University Press, Oxford) pp $91-120$

Lembruch G, 1994, "Institutionen, Interessen und sektorale Variationen in der Transformationsdynamik der politischen Ökonomie Ostdeutschlands" Journal für Sozialforschung 3421 - 44

Locke R, Jacoby W, 1997, "The dilemmas of diffusion: institutional transfer and the remaking of vocational training practices in Eastern Germany", in Negotiating the New Germany

Ed. L Turner (ILR Press - Cornell University Press, Ithaca, NY) pp 33-62

Mayntz R, 2004, "Mechanisms in the analysis of social macro-phenomena" Philosophy of the Social Sciences $34237-259$

Pierson P, 2000, "Increasing returns, path dependence and the study of politics" American Political Science Review 94251 - 267

Rauner F, 2003, "Ausbildungspartnerschaften als Regelmodell für die Organisation der dualen Berufsausbildung?" ITB-Forschungsberichte 12, http://www.itb.uni-bremen.de/fileadmin/ Download/publikationen/forschungsberichte/fb_12_03.pdf

Rehder B, 2003, "Konversion durch Überlagerung: der Beitrag betrieblicher Bündnisse zum Wandel der Arbeitsbeziehungen", in Vom Zukunfts- zum Auslaufmodell? Ed. J Beyer (Westdeutscher Verlag, Wiesbaden) pp $61-77$

Schmidt R, 1998 Mitbestimmung in Ostdeutschland (Verlag Bertelmann Stiftung, Gütersloh)

Schmierl K, 2003, "Vielfalt im Umbruch: Auflösungserscheinungen, Anpassungsprozesse und neue Interessenvertretungsmodelle in den Arbeitsbeziehungen", in Vom Zukunfts- zum Auslaufmodell? Ed. J Beyer (Westdeutscher Verlag, Wiesbaden) pp 36-60

Schroeder W, 2000 Das deutsche Modell auf dem Prüfstand: Zur Entwicklung der industriellen Beziehungen in Ostdeutschland (Westdeutscher Verlag, Wiesbaden)

Silvia S J, 1997, "German unification and emerging divisions within German employers' associations" Comparative Politics 29 187-208

Streeck W, 1997, “German capitalism: does it exist? Can it survive?” New Political Economy 2 $237-256$

Streeck W, Thelen K, 2005, "Introduction: institutional change in advanced political economies", in Beyond Continuity: Institutional Change in Advanced Political Economies Eds W Streeck, K Thelen (Oxford University Press, Oxford) pp 1-39

Thelen K, 2004 How Institutions Evolve (Cambridge University Press, New York)

Thelen K, 2007, "Contemporary challenges to the German vocational training system" Regulation and Governance $1247-260$

Tolliday S, Boyer R, Charron E, Jürgens U, 1998, "Introduction: between imitation and innovation: the transfer and hybridization of productive models in the international automobile industry", in Between Imitation and Innovation: The Transfer and Hybridization of Productive Models in the International Automobile Industry Eds R Boyer, E Charron, U Jürgens, S Tolliday (Oxford University Press, Oxford) pp $1-19$

Turner L (Ed.), 1997 Negotiating the New Germany (ILR Press, Ithaca, NY)

Turner L, 1998 Fighting for Partnership: Labor and Politics in Unified Germany (Cornell University Press, Ithaca, NY)

Ulrich J G, Eberhard V, 2008, "Die Entwicklung des Ausbildungsmarktes in Deutschland seit der Wiedervereinigung", in Ausbildungschancen und Verbleib von Schulabsolventen Eds U Beicht, M Friedrich, J Ulrich (Bundesinstitut für Berufsbildung, Bonn) pp 13-57

Whitley R, 1994, "The internationalization of firms and markets: its significance and institutional structuring” Organization $1101-124$

Wiesenthal H, 2004, "German unification and 'model Germany': an adventure in institutional conservatism", in Germany: Beyond the Stable State Eds H Kitschelt, W Streeck (Frank Cass, London) pp $37-58$

Womack J P, Jones D T, Roos D, 1990 The Machine that Changed the World (Macmillan, New York) WSI-Tarifsarchiv, 2008, http://www.boeckler.de/549_19392.html 
Conditions of use. This article may be downloaded from the E\&P website for personal research by members of subscribing organisations. This PDF may not be placed on any website (or other online distribution system) without permission of the publisher. 